10

\title{
Joint quantification of PAH and oxy-PAH from standard reference materials (urban dust and diesel particulate matter) and diesel soot surrogate by GC-MS
}

\author{
F. Viteri ${ }^{\text {b,a }}$, D. Pezo ${ }^{\text {a }}$ Á. Millera ${ }^{a}$, R. Bilbao ${ }^{\text {a }}$, M.U. Alzueta ${ }^{a}$ \\ ${ }^{a}$ Aragón Institute of Engineering Research (I3A), Department of Chemical and Environmental Engineering, \\ University of Zaragoza, Zaragoza 50018, Spain \\ ${ }^{b}$ Facultad de Ciencias de la Ingeniería e Industrias. Universidad UTE. Quito - Ecuador. \\ *Corresponding author: Phone: +34976761876, e-mail address: uxue@unizar.es
}




\section{Abstract}

The combustion of fossil fuels produces pollutants such as soot, which consists of carbonaceous particles whose emission is regulated by environmental laws. Soot is mainly formed from polycyclic aromatic hydrocarbons $(\mathrm{PAH})$, through different reaction ways and, once formed, it can adsorb PAH on its surface. These compounds have an environmental importance due to their carcinogenic and mutagenic potential. In the last years, the oxygenated derivatives of PAH (oxy-PAH) have also been considered as dangerous since they have been found to be mutagenic for bacterial and human cells. Therefore, the purpose of this work was to quantify simultaneously selected PAH and oxy-PAH from different samples of soot. The quantification method involves Soxhlet extraction and subsequent concentration by rotary evaporation that allows to recover the analysed compounds from soot samples. The PAH and oxy-PAH were identified and quantified, by a single injection, using a gas chromatograph-mass spectrometer (GC-MS). The method showed a good repeatability using a diesel soot surrogate test sample, Printex-U. The validation process showed that most of the compounds are recovered between the values established for the Standard Reference Materials analysed, 1650b and 1649b. The values of the mass fraction of the oxy-PAH obtained in this work showed, in general, a good match with those indicated in other studies.

Keywords: Polycyclic aromatic hydrocarbons (PAH), oxygenated polycyclic aromatic hydrocarbons (oxy-PAH), gas chromatography-mass spectrometry (GC-MS), Standard Reference Materials (SRM), diesel, soxhlet extraction. 


\section{Introduction}

The atmospheric pollutant emissions are mainly produced in the combustion processes, especially through the combustion of fossil fuels. Among the common pollutants, the particulate matter is one of the most controlled by environmental regulations and a significant fraction of it is soot, a carbonaceous material formed in the combustion process. Soot is produced through the polycyclic aromatic hydrocarbons (PAH) formed in rich fuel conditions. PAH formation and consecutive soot production are explained by some mechanisms such as the hydrogen-abstraction/acetylene-addition (HACA) route, the combinative growth mechanism, and the cyclopentadienyl recombination (Richter and Howard 2000). Oxy-PAH can also be formed directly from combustion processes or in the atmosphere from PAH induced oxidation (Allen et al. 1997; Albinet et al. 2008). Thus, 9-fluorenone; 9,10 anthraquinone; benzanthrone and benz-[a]anthracene-7,12-dione are the most abundant oxy-PAH found in ambient air (Shen et al. 2011).

Moreover, polycyclic aromatic hydrocarbons can be adsorbed on soot surface (Mathieu et al. 2007) and could be hazardous for human health, due to their toxic character (Bosetti et al. 2007). The toxicity of the PAH has been repeatedly demonstrated (Durant et al. 1996), being benzo $[a]$ pyrene used in many environmental studies as a toxicity reference compound (Hattemer-Frey and Travis 1991; Masiol et al. 2012; Pongpiachan et al. 2015). The US Environmental Protection Agency (EPA) has established a list of $16 \mathrm{PAH}$ as priority pollutants (EPA-PAH) found in the atmosphere, due to their carcinogenic potential.

In this way, oxy-PAH have also been studied in order to determine their toxicity (Lampi et al. 2005; Fu et al. 2012), in particular in human cells (Durant et al. 1996), where some ketones and quinones such as benzanthrone and benzo[cd]pyrenone are denoted as mutagenic compounds. Consequently, oxy-PAH have to be considered, according to Lundstedt et al. (2007), for monitoring programs in contaminated sites due to their high mobility in the 
environment. Hence, some studies involved in control of atmospheric pollution have considered important to measure together oxy-PAH and PAH in urban air (Walgraeve et al. 2015; Bandowe et al. 2014).

The quantification of PAH and oxy-PAH has been performed through different procedures. A method of quantification of the 16 most important EPA-PAH, from solid and gas phases, has been developed previously by our group. The method includes Soxhlet extraction, concentration by rotary evaporation and subsequent gas chromatography mass spectrometry (GC-MS) analysis (Sánchez et al. 2013). On the other hand, oxy-PAH have been quantified in different works. Nocun and Schantz (2013) and Layshock et al. (2010) used pressurized liquid extraction (PLE) and later analysis with GC-MS. O'Connell et al. (2013) quantified oxy-PAH by GC-MS and liquid chromatography-atmospheric pressure chemical ionization-mass spectrometry (LC-APCI-MS) and Ahmed et al. (2015) used liquid chromatography-gas chromatography-mass spectrometry system (LC-GC-MS). The works mentioned above have employed different Standard Reference Materials (SRM) to validate their analytical methodology.

In this context, it has been considered interesting to develop a relatively simple method through Soxhlet extraction, concentration by rotary evaporation and GC-MS analysis, that allow us to quantify simultaneously selected PAH and oxy-PAH. Printex-U was used to test the repeatability of the method and two Standard Reference Materials (SRM) to validate the results.

\section{Materials and methods}

\subsection{Reagents}

A PAH standard mixture (PAH-Mix 63, Dr. Ehrenstorfer-Shäfers) containing the 16 EPAPAH, and an oxy-PAH standard mixture (PAH Special Mix 7, A2S Analytical Standard Solutions) containing 7 selected oxy-PAH, were employed for calibration purposes. Mix of the 
PAH standards (Naphtalene, Acenaphthylene, Acenaphthene, Fluorene, Phenanthrene, Anthracene, Fluoranthene, Pyrene, Benzo[a]anthracene, Chrysene, Benzo[b]fluoranthene, Benzo[k]fluoranthene, Benzo[a]pyrene, Indeno[1,2,3-cd]pyrene, Dibenz $[a h]$ anthracene, Benzo[ghi]perylene), mix of the deuterated standards of PAH (Acenaphthene $\mathrm{d}_{10}$, Chrysene $\mathrm{d}_{12}$, Naphthalene $\mathrm{d}_{8}$, Perylene $\mathrm{d}_{12}$, Phenanthrene $\mathrm{d}_{10}$ ) and deuterated standard of injection Anthracene $d_{10}$ were supplied by Dr. Ehrenstorfer-Shäfers. Mix of the standards of oxy-PAH (Benzo[cd]pyrenone, 9,10-anthraquinone, 9-fluorenone, Benzo[a]fluorenone, Benzo[a]anthracene-7,12-dione, Naphthacene-5,12-dione, Benzanthrone) and mix of the deuterated standards of oxy-PAH (9,10-Anthraquinone $\mathrm{d}_{8}$, 9-Fluorenone $\left.\mathrm{d}_{8}\right)$ were supplied by A2S Analytical Standard Solutions.

\subsection{Experimental methodology}

The analytical method consists of a combination of Soxhlet extraction, concentration of the extract by rotary evaporation and subsequent analysis by gas chromatography-mass spectrometry. The Soxhlet extraction system was operated according to the EPA method 3540C recommendations. The solvent used during the Soxhlet extraction and in the calibration was dichloromethane (DCM) 99.5\%. The packaging of the cellulose cartridges employed was the same as used in the method developed by Sánchez et al. (2013). The temperature during the extraction was $40^{\circ} \mathrm{C}$ and the extraction time was 24 hours with 4 cycles per hour. Recommendations of EPA methods $8270 \mathrm{D}$ and TO-13A for determination of semivolatile organic compounds and toxic organic air pollutants were taken as a reference. Internal standards were used for correcting the possible losses of analytes during sample preparation, since chromatographic signal of both, target compounds and their internal standards, have similar responses. Calibration curves with eight concentrations levels were built. Samples of PrintexU, a commercial carbon black considered as diesel soot surrogate (Arnal et al. 2012), were used 
to test the repeatability of the method. Printex-U has been employed in different works with the aim to verify the repeatability of a method (Sadezky et al. 2005; Atribak et al. 2010).

In order to validate the results, Standards Reference Materials, Diesel Particulate Matter (1650b) (NIST 2013) and Urban Dust (1649b) (NIST 2009), were taken to verify the amount of each PAH and oxy-PAH obtained in each analysis of quantification. Additionally, a comparison between obtained results and those corresponding to other works was done in order to check the accuracy of the present method. The PAH and oxy-PAH were jointly detected and quantified by GC-MS.

\subsection{Instrumentation}

The extracts were analysed using GC with MS (Agilent 7890A gas chromatograph coupled to an Agilent 5975C mass selective detector) operated in electron impact mode using a capillary column DB-17ms (Agilent $60 \mathrm{~m} \times 0.25 \mathrm{~mm} \times 0.25 \mu \mathrm{m}$ ) with medium polarity, being identified such as the one that provides the best results of PAH quantification, through chromatographic analysis (Gómez and Wenzl 2009).

The chromatographic conditions always included helium as carrier gas $\left(1 \mathrm{~mL} \mathrm{~min}^{-1}\right)$ and 2 $\mu \mathrm{L}$ of injection volume in splitless mode. The temperature program started at $60^{\circ} \mathrm{C}$, raised $5^{\circ} \mathrm{C}$ $\min ^{-1}$ up to $190^{\circ} \mathrm{C}$, then $1.5^{\circ} \mathrm{C} \min ^{-1}$ up to $226^{\circ} \mathrm{C}$, then raised $2.5^{\circ} \mathrm{C} \mathrm{min}-1$ up to $288^{\circ} \mathrm{C}$, finally raised $1^{\circ} \mathrm{C} \min ^{-1}$ up to $320^{\circ} \mathrm{C}$ and held for $12 \mathrm{~min}$. The transfer line temperature was $320^{\circ} \mathrm{C}$. The initial ion identification and determination of retention times were done using the NIST spectral library, operating in SCAN mode. Once the compounds were clearly identified, the analysis was performed with the selected ion monitoring (SIM), in order to increase the sensitivity of the method.

\section{Results and discussion}


Qualitative analysis of extracts of different soot samples such as Printex-U and Standard

136 Reference Materials (SRM) 1649b and 1650b, was done in SCAN mode with the acquisition

137 mass range from 40 to $400 \mathrm{~m} / \mathrm{z}$, as can be seen in the chromatograms shown in the Figures 1,2

138 and 3 respectively. 157 compounds were qualified in the three samples, and the results are

139 shown in the Table S1 of the Supplementary Material.

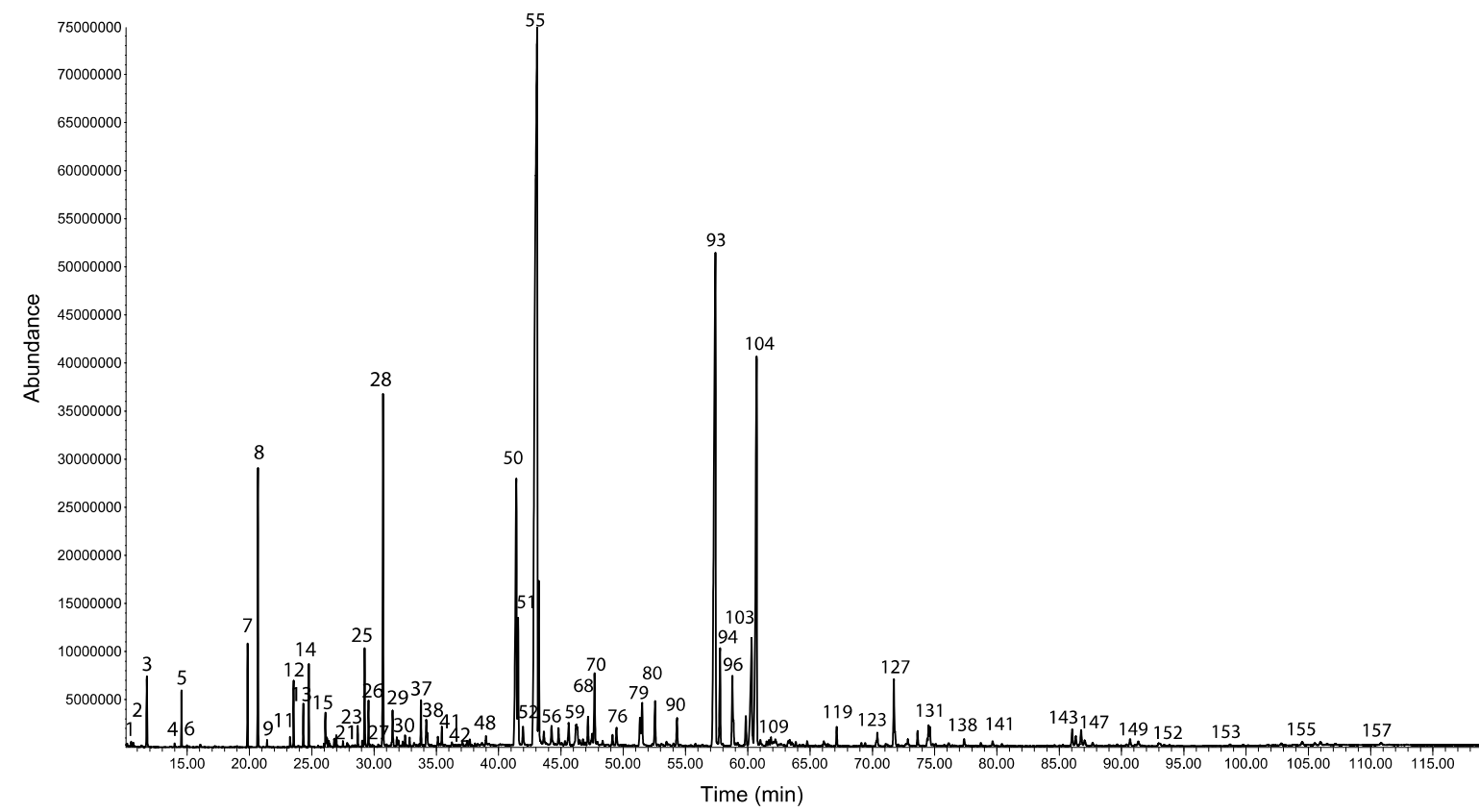

Fig. 1 GC chromatogram of the Printex-U sample in SCAN mode on a DB-17MS column 


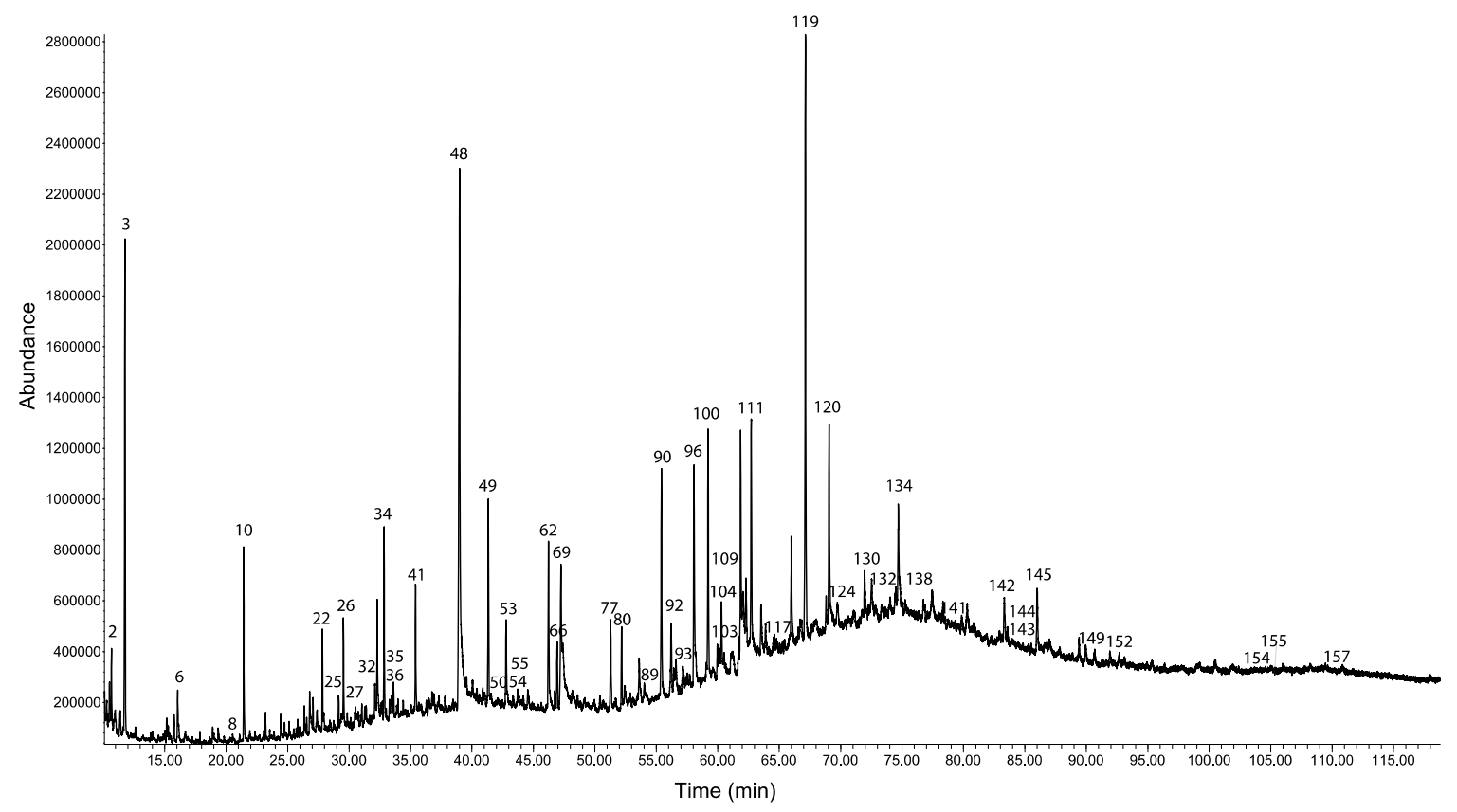

Fig. 2 GC chromatogram of the SRM 1649b sample in SCAN mode on a DB-17MS column

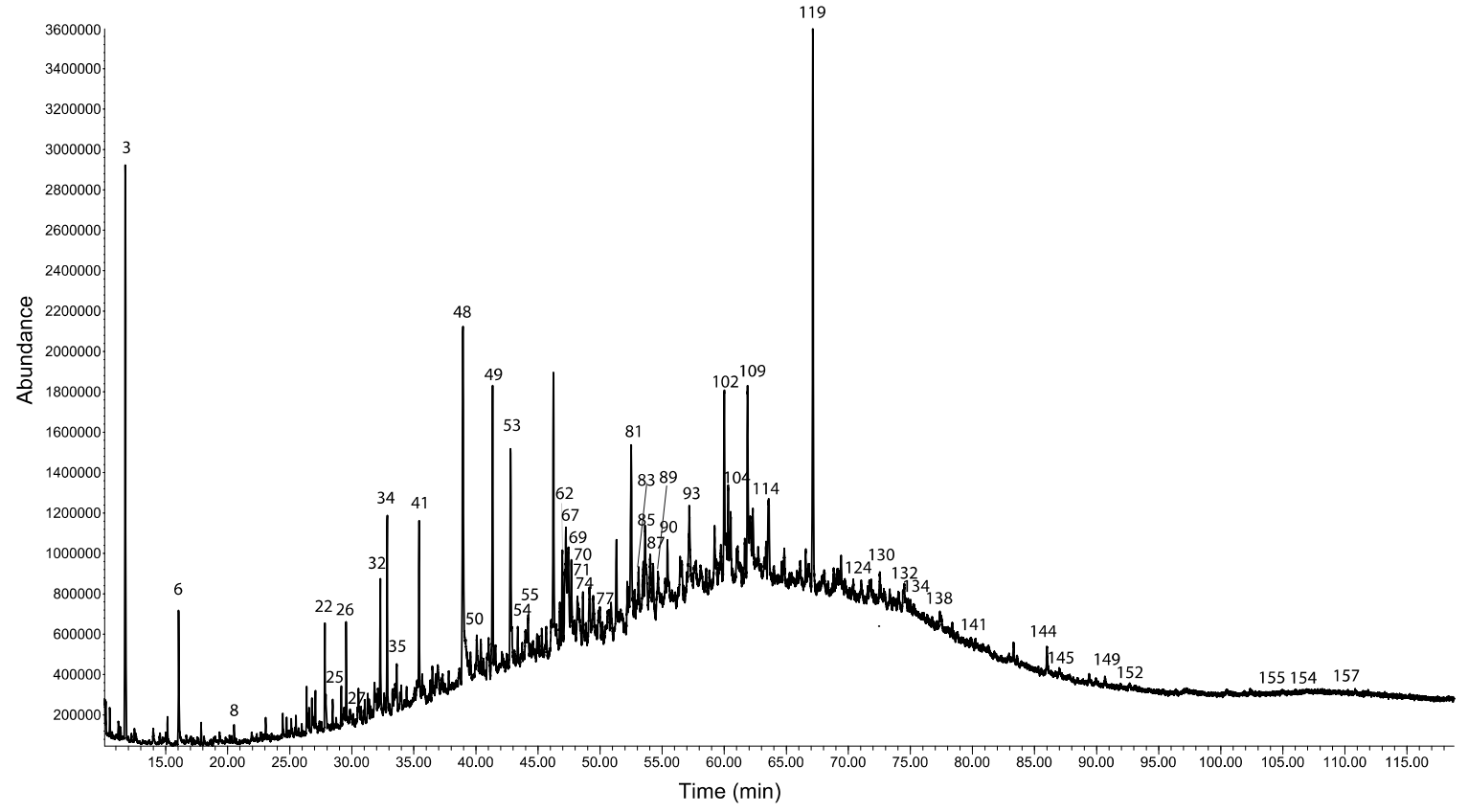

Fig. 3 GC chromatogram of the SRM 1650b sample in SCAN mode on a DB-17MS column. identification was considered when match was above 70. Otherwise, the identification was only considered as indicative. 
The linear fitting of the obtained calibration curves for each compound, indicated in section

1532.1 , showed correlation coefficients $(r)$ between 0.988 and 0.999 within the linear range (469

$\left.154 \mathrm{ng} \mathrm{mL} L^{-1}-50000 \mathrm{ng} \mathrm{mL} L^{-1}\right)$. The calibration curves were prepared in triplicate. The quantification 155 was carried out with the selected ion monitoring (SIM). The detection limit (LOD) and the 156 quantification limit (LOQ) with $95 \%$ of confidence level were also established, Table 1. 
Table 1. Compounds and analytical parameters.

\begin{tabular}{|c|c|c|c|c|c|c|c|}
\hline Compound & $\begin{array}{l}\text { Molecular } \\
\text { formula }\end{array}$ & Abbreviation & $\begin{array}{l}\text { Monitored } \\
\text { ions }\end{array}$ & $\begin{array}{c}\text { RT } \\
(\min )\end{array}$ & $r$ & $\begin{array}{c}\text { Limit of } \\
\text { detection } \\
\text { LOD }(\mathrm{ng} / \mathrm{mL}) \\
\end{array}$ & $\begin{array}{c}\text { Limit of } \\
\text { quantification } \\
\text { LOQ }(\mathrm{ng} / \mathrm{mL}) \\
\end{array}$ \\
\hline Naphthalene $^{1}$ & $\mathrm{C}_{10} \mathrm{H}_{8}$ & NAPH & $128-129$ & 18.909 & 0.997 & 11.32 & 34.32 \\
\hline Acenaphthylene $^{1}$ & $\mathrm{C}_{12} \mathrm{H}_{8}$ & $\mathrm{ACNY}$ & $152-153$ & 27.308 & 0.997 & 16.82 & 50.98 \\
\hline Acenaphthene $^{1}$ & $\mathrm{C}_{12} \mathrm{H}_{10}$ & $\mathrm{ACN}$ & $154-153$ & 27.992 & 0.997 & 13.85 & 41.96 \\
\hline Fluorene $^{1}$ & $\mathrm{C}_{13} \mathrm{H}_{10}$ & FLUO & $166-165$ & 30.964 & 0.997 & 19.69 & 59.66 \\
\hline 9-fluorenone ${ }^{2}$ & $\mathrm{C}_{13} \mathrm{H}_{8} \mathrm{O}$ & 9-FLUO & $180-152$ & 38.433 & 0.997 & 19.59 & 59.36 \\
\hline Phenanthrene ${ }^{1}$ & $\mathrm{C}_{14} \mathrm{H}_{10}$ & PHEN & $178-179$ & 39.821 & 0.997 & 16.37 & 49.59 \\
\hline Anthracene $^{1}$ & $\mathrm{C}_{14} \mathrm{H}_{10}$ & ANTH & $178-179$ & 40.102 & 0.996 & 24.40 & 73.95 \\
\hline 9,10 -anthraquinone ${ }^{2}$ & $\mathrm{C}_{14} \mathrm{H}_{8} \mathrm{O}_{2}$ & 9,10-ANTH & $208-152$ & 50.996 & 0.999 & 15.56 & 47.17 \\
\hline Fluoranthene $^{1}$ & $\mathrm{C}_{16} \mathrm{H}_{10}$ & FANTH & $202-203$ & 53.932 & 0.997 & 14.99 & 45.45 \\
\hline Pyrene $^{1}$ & $\mathrm{C}_{16} \mathrm{H}_{10}$ & PYR & $202-203$ & 57.336 & 0.991 & 16.00 & 48.49 \\
\hline Benzofluorenone $^{2}$ & $\mathrm{C}_{17} \mathrm{H}_{10} \mathrm{O}$ & BFLUO & $230-202$ & 67.442 & 0.998 & 23.46 & 71.10 \\
\hline Benzo $[a]$ anthracene $^{1}$ & $\mathrm{C}_{18} \mathrm{H}_{12}$ & $\mathrm{~B}[a] \mathrm{A}$ & $228-226$ & 70.696 & 0.998 & 24.08 & 72.96 \\
\hline Chrysene $^{1}$ & $\mathrm{C}_{18} \mathrm{H}_{12}$ & CHR & $228-226$ & 71.594 & 0.997 & 19.40 & 58.79 \\
\hline Benzanthrone $^{2}$ & $\mathrm{C}_{17} \mathrm{H}_{10} \mathrm{O}$ & BEZO & $230-202$ & 74.396 & 0.996 & 29.85 & 90.46 \\
\hline $\begin{array}{l}\text { Benzo }[a] \text { anthracene-7,12- } \\
\text { dione }^{2}\end{array}$ & $\mathrm{C}_{18} \mathrm{H}_{10} \mathrm{O}_{2}$ & 7,12-BaAQ & $258-202$ & 76.765 & 0.999 & 33.05 & 110.16 \\
\hline Naphthacene-5,12-dione ${ }^{2}$ & $\mathrm{C}_{18} \mathrm{H}_{10} \mathrm{O}_{2}$ & 5,12-NAPQ & $258-202$ & 80.308 & 0.988 & 55.25 & 184.17 \\
\hline Benzo $[b]$ fluoranthene ${ }^{1}$ & $\mathrm{C}_{20} \mathrm{H}_{12}$ & $\mathrm{~B}[b] \mathrm{F}$ & $252-253$ & 82.433 & 0.992 & 28.77 & 87.18 \\
\hline Benzo $[k]$ fluoranthene ${ }^{1}$ & $\mathrm{C}_{20} \mathrm{H}_{12}$ & $\mathrm{~B}[k] \mathrm{F}$ & $252-253$ & 82.708 & 0.988 & 45.11 & 136.71 \\
\hline $\operatorname{Benzo}_{a}[]_{\text {pyrene }}{ }^{1}$ & $\mathrm{C}_{20} \mathrm{H}_{12}$ & $\mathrm{~B}[a] \mathrm{P}$ & $252-253$ & 87.353 & 0.993 & 26.53 & 80.39 \\
\hline Benzo $[c d]$ pyrenone ${ }^{2}$ & $\mathrm{C}_{18} \mathrm{H}_{10} \mathrm{O}$ & $\mathrm{B}[c d] \mathrm{PYRO}$ & $254-226$ & 89.047 & 0.994 & 121.94 & 406.46 \\
\hline Indeno $[1,2,3-c d]$ pyrene $^{1}$ & $\mathrm{C}_{22} \mathrm{H}_{12}$ & $\mathrm{I}[123-c d] \mathrm{P}$ & $276-277$ & 101.197 & 0.990 & 31.48 & 95.38 \\
\hline Dibenz $[a h]$ anthracene $^{1}$ & $\mathrm{C}_{22} \mathrm{H}_{14}$ & $\mathrm{DB}[a h] \mathrm{A}$ & $278-279$ & 101.339 & 0.989 & 38.43 & 116.45 \\
\hline Benzo[ghi]perylene ${ }^{1}$ & $\mathrm{C}_{22} \mathrm{H}_{12}$ & $\mathrm{~B}[g h i] \mathrm{P}$ & $276-277$ & 105.639 & 0.994 & 22.60 & 68.50 \\
\hline
\end{tabular}

$159{ }^{1}$ Polycyclic aromatic hydrocarbons (PAH)

$160{ }^{2}$ Oxygenated Polycyclic aromatic hydrocarbons (oxy-PAH)

161 The chromatogram of standards and deuterated compounds used in the extraction and 162 quantification process can be seen in Figure 4. 




163

Fig. 4 Chromatogram of PAH, oxy-PAH and deuterated compounds acquired in SIM mode on a DB-17MS column using GC-Ms.

\subsection{Repeatability}

The repeatability of presented method was evaluated using Printex-U samples, considering for this purpose the results of three repetitions, using in each one $1500 \mathrm{mg}$ of Printex-U.

Table 2 shows the average mass fraction values of the analysed PAH and oxy-PAH and their Relative Standard Deviation (RSD) values. This is a criteria acceptance for chromatographic methods, where the RSD value should be below 20\% (Mahuzier et al. 2001; Choi et al. 2016). Thus, most of the obtained RSD values were lower than $27 \%$, which can be taken as a good reference for the different quantified analytes. It can be also noticed that the higher the molecular mass was, the higher obtained. RSD value was. 
Table 2. Average mass fraction values of PAH and oxy-PAH from Printex-U.

\begin{tabular}{lcc}
\hline Compounds & $\begin{array}{c}\text { Average concentration }(\mathbf{n}=\mathbf{3}) \\
(\mathbf{m g} / \mathbf{k g})\end{array}$ & RSD (\%) \\
\hline NAPH & 66.48 & 5.99 \\
ACNY & 33.82 & 6.43 \\
ACN & 0.22 & 7.30 \\
FLUO & 1.21 & 11.25 \\
9-FLUO & 164.02 & 5.47 \\
PHEN & 857.76 & 6.34 \\
ANTH & 80.97 & 2.25 \\
FANTH & 294.77 & 8.65 \\
9,10-ANTH & 8.53 & 6.53 \\
PYR & 277.54 & 9.08 \\
B[a]A & 6.17 & 16.98 \\
BFLUO & 6.07 & 17.35 \\
BEZO & 3.25 & 25.13 \\
CHR & 10.17 & 17.28 \\
$7,12-B a A Q$ & $B D L$ & - \\
$5,12-N A P Q$ & 1.19 & 27.02 \\
B[cd]PYRO & 11.2 & 14.21 \\
B[b]F & 12.85 & 12.38 \\
B[k]F & 6.23 & 17.17 \\
B[a]P & 5.06 & 19.36 \\
I[123-cd]P & 3.87 & 16.66 \\
DB[ah]A & 0.38 & 22.57 \\
B[ghi]P & 5.69 & 27.14 \\
\hline & & \\
\hline
\end{tabular}

178 Figure 5 shows the repeatability analysis performed with Printex-U sample. It can be seen

179 that repetitions have a high precision due to low differences among them.

180 The PAH mass fraction recovered in the present study are similar to those obtained by

181 Sánchez et al. (2013), where PHEN were found in high amount and light PAH, such as NAPH and ACNY, were found in low amounts. 

method is guaranteed.

\subsection{Validation}



Fig 5. Repeatability obtained for Printex-U sample.

The quantification analysis was validated using the following SRM: Diesel Particulate Matter (SRM 1650b) and Urban Dust (SRM 1649b). These SRM were commonly used in analytical works (Nocun and Schantz 2013; Layshock et al. 2010; O'Connell et al. 2013; Ahmed et al. 2015) in order to verify that the amount of the compounds obtained in each analysis corresponds to a certified value of its concentration. In this way, a high accuracy of the 
Table 3. Average mass fraction values compared to certified/referenced concentration for SRM 1650b (standard deviations in parentheses).

\begin{tabular}{lcc}
\hline Compounds & $\begin{array}{c}\text { Average concentration } \\
(\mathbf{n}=\mathbf{3})(\mathbf{m g} / \mathbf{k g})\end{array}$ & $\begin{array}{c}\text { Certified or } \\
\text { referenced } \\
\text { concentration } \\
(\mathbf{m g} / \mathbf{k g})\end{array}$ \\
\hline NAPH & $3.69(1.03)$ & $5.16^{\mathrm{b}}$ \\
ACNY & $1.38(0.68)$ & $1.36^{\mathrm{b}}$ \\
ACN & $0.28(0.05)$ & $0.23^{\mathrm{b}}$ \\
FLUO & $0.95(0.01)$ & $0.76^{\mathrm{b}}$ \\
9-FLUO & $20.46(1.44)$ & $\mathrm{NR}$ \\
PHEN & $43.18(2.01)$ & $65.61^{\mathrm{a}}$ \\
ANTH & $5.75(0.46)$ & $7.58^{\mathrm{b}}$ \\
FANTH & $28.72(2.46)$ & $48.10^{\mathrm{a}}$ \\
9,10-ANTH & $31.39(1.89)$ & $\mathrm{NR}$ \\
PYR & $43.87(7.62)$ & $44.10^{\mathrm{a}}$ \\
B[a]A & $5.66(1.85)$ & $6.45^{\mathrm{a}}$ \\
BFLUO & $8.78(1.99)$ & $\mathrm{NR}$ \\
BEZO & $7.34(1.14)$ & $\mathrm{NR}$ \\
CHR & $8.53(3.61)$ & $13.40^{\mathrm{a}}$ \\
7,12-BaAQ & $\mathrm{BDL}$ & $\mathrm{NR}$ \\
$5,12-\mathrm{NAPQ}$ & $\mathrm{BDL}$ & $\mathrm{NR}$ \\
B[cd]PYRO & $28.99(1.29)$ & $\mathrm{NR}$ \\
B[b]F & $4.99(1.77)$ & $6.77^{\mathrm{a}}$ \\
B[k]F & $2.08(1.67)$ & $2.30^{\mathrm{a}}$ \\
B[a]P & $2.08(0.33)$ & $1.25^{\mathrm{a}}$ \\
I[123-cd]P & $4.66(2.42)$ & $4.48^{\mathrm{a}}$ \\
DB[ah]A & $0.67(0.34)$ & $0.37^{\mathrm{a}}$ \\
B[ghi]P & $10.25(1.98)$ & $6.04^{\mathrm{a}}$ \\
\hline
\end{tabular}

${ }^{a}$ Compared to certified values, mass fraction $(\mathrm{mg} / \mathrm{kg})$

${ }^{\mathrm{b}}$ Compared to reference values, mass fraction $(\mathrm{mg} / \mathrm{kg})$ BDL (Below detection limit) NR (No reference)

Three samples of each SRM were used (each sample of $100 \mathrm{mg}$ in case of SRM 1649b and $30 \mathrm{mg}$ in case of SRM 1650b) and analysed to verify the quantified values through the present method.

Tables 3 and 4 show the comparison between the mass fraction values obtained using the presented method with the certified/reference values of mass fragment found for SRM 1650b and SRM 1649b. Two oxy-PAH: 7,12-BaAQ and 5,12-NAPQ could not be detected for analysed SRM samples and were below detection limit (BDL). Only it was possible the comparison for 7,12-BaAQ because the mass fraction of this compound reported in the SRM $1649 \mathrm{~b}$ is $3.6 \mathrm{mg} / \mathrm{kg}$. 
Table 4. Average mass fraction values compared to certified/referenced concentration for SRM 1649b (standard deviations in parentheses).

\begin{tabular}{|c|c|c|}
\hline Compounds & $\begin{array}{c}\text { Average } \\
\text { concentration } \\
(\mathrm{n}=3)(\mathbf{m g} / \mathbf{k g})\end{array}$ & $\begin{array}{c}\text { Certified or } \\
\text { referenced } \\
\text { concentration } \\
(\mathrm{mg} / \mathrm{kg})\end{array}$ \\
\hline$\overline{\mathrm{NAPH}}$ & $1.15(0.18)$ & $1.12^{\mathrm{b}}$ \\
\hline $\mathrm{ACNY}$ & $0.29(0.05)$ & $0.18^{\mathrm{b}}$ \\
\hline $\mathrm{ACN}$ & $0.16(0.03)$ & $0.19^{b}$ \\
\hline FLUO & $0.16(0.02)$ & $0.22^{\mathrm{b}}$ \\
\hline 9-FLUO & $1.12(0.17)$ & $1.40^{\mathrm{c}}$ \\
\hline PHEN & $3.71(0.11)$ & $3.94^{\mathrm{a}}$ \\
\hline ANTH & $0.54(0.04)$ & $0.40^{\mathrm{b}}$ \\
\hline FANTH & $3.91(0.18)$ & $6.14^{\mathrm{a}}$ \\
\hline 9,10-ANTH & $1.87(0.28)$ & $1.80^{\mathrm{c}}$ \\
\hline PYR & $6.06(0.79)$ & $4.78^{\mathrm{a}}$ \\
\hline $\mathrm{B}[a] \mathrm{A}$ & $1.45(0.08)$ & $2.09^{\mathrm{a}}$ \\
\hline BFLUO & $1.14(0.09)$ & NR \\
\hline BEZO & $1.54(0.12)$ & $1.60^{\mathrm{c}}$ \\
\hline CHR & $2.63(0.076)$ & $3.01^{\mathrm{a}}$ \\
\hline 7,12-BaAQ & $3.82(1.49)$ & $3.60^{\mathrm{a}}$ \\
\hline 5,12-NAPQ & $2.39(0.33)$ & NR \\
\hline $\mathrm{B}[c d] \mathrm{PYRO}$ & $21.60(8.68)$ & NR \\
\hline $\mathrm{B}[b] \mathrm{F}$ & $4.43(0.26)$ & $5.99^{\mathrm{a}}$ \\
\hline $\mathrm{B}[k] \mathrm{F}$ & $1.07(0.13)$ & $1.75^{\mathrm{a}}$ \\
\hline $\mathrm{B}[a] \mathrm{P}$ & $2.49(1.41)$ & $2.47^{\mathrm{a}}$ \\
\hline $\mathrm{I}[123-c d] \mathrm{P}$ & $2.50(0.63)$ & $2.96^{\mathrm{a}}$ \\
\hline $\mathrm{DB}[a h] \mathrm{A}$ & $0.38(0.03)$ & $0.29^{\mathrm{a}}$ \\
\hline $\mathrm{B}[g h i] \mathrm{P}$ & $5.66(0.76)$ & $3.94^{\mathrm{a}}$ \\
\hline
\end{tabular}

Table 4 shows that the quantified amount of 9-FLUO is slightly lower and 9,10-ANTH is 216 slightly higher, compared to the theoretical concentrations. This results are similar to those 217 found in a previous study that analysed SRM 1649b (Albinet et al. 2006). quantified analyte. 


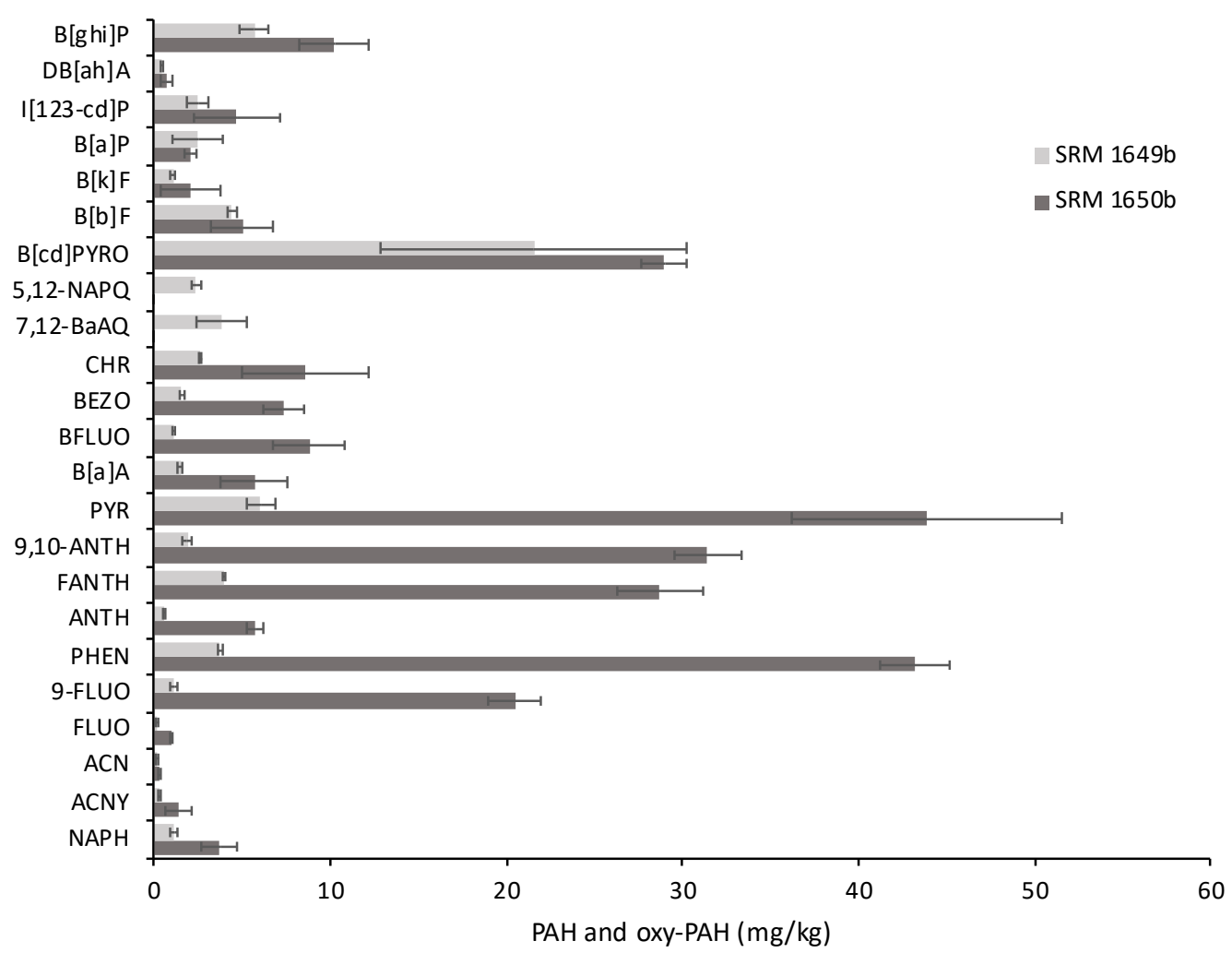

Fig. 6. Mass fraction and standard deviations of PAH and oxy-PAH from SRM 1650b and 1649b.

Due to a lack of standard reference values, a comparison between the results obtained in different studies (Nocun and Schantz 2013; Layshock et al. 2010; O’Connell et al. 2013) was performed for validation purposes of oxy-PAH compounds. The comparison was done between studies that employed GC-MS analysis but with differences in the extraction method and chromatographic columns, Tables 5 and 6 . In the present work, Soxhlet extraction was applied, while pressurized liquid extraction (PLE) was used for the rest of studies. Although PLE has higher extraction efficiencies, especially in PAH extraction from diesel particulate matter, compared to Soxhlet extraction (Schantz 2006), the present results show acceptable quantified concentrations for analysed analytes.

Additionally, Nocun and Schantz (2013) employed the same chromatographic column (DB17-MS) as in the present study. Nevertheless, Layshock et al. (2010) and O'Connell et al. (2013) used a DB5-MS column. 
As it was mentioned above, two compounds (oxy-PAH) have not been detected in the

237 present analysis. The same result was observed by Nocun and Schantz (2013), Layshock et al.

238 (2010) and O'Connell et al. (2013) for 5,12-NAPQ in the SRM 1650b analysis.

The mass fraction values of oxy-PAH recovered from SRM 1649b were similar to the values

241 for values recovered for BEZO, compared with the studies done by Nocun and Schantz (2013)

242 and Layshock et al. (2010).

On the other hand, the mass fraction values of 9,10-ANTH, BFLUO and BEZO from SRM and BEZO were in line with the values reported for SRM 1649b. In case of B $[c d]$ PYRO found in both samples mass fraction values were different comparing to the other authors.

Table 5. Mass fraction values reported in mg/kg for oxy-PAH from SRM 1649b.

\begin{tabular}{lcccc}
\cline { 2 - 4 } & $\begin{array}{c}\text { Present work } \\
(\mathbf{n = 3})\end{array}$ & $\begin{array}{c}\text { Nocun and } \\
\text { Schantz (2013) } \\
(\mathbf{n}=\mathbf{3})\end{array}$ & $\begin{array}{c}\text { Layshock et al. } \\
\mathbf{( 2 0 1 0 )} \\
(\mathbf{n}=\mathbf{3})\end{array}$ & $\begin{array}{c}\text { O'Connell et al. } \\
\mathbf{( 2 0 1 3 )} \\
(\mathbf{n}=\mathbf{5})\end{array}$ \\
\hline 9-FLUO & 1.12 & 1.19 & 0.78 & 0.76 \\
9,10-ANTH & 1.87 & 1.39 & 1.60 & 2.6 \\
BFLUO & 1.14 & 1.88 & 1.65 & 0.78 \\
BEZO & 1.54 & 3.13 & 4.46 & 1.18 \\
7,12-BaAQ & 3.82 & 3.75 & 3.16 & 1.4 \\
5,12-NAPQ & 2.39 & 1.25 & 2.20 & 0.72 \\
B[cd]PYRO & 21.60 & 4.19 & 2.42 & 0.56 \\
\hline
\end{tabular}

Table 6. Mass fraction values reported in mg/kg for oxy-PAH from SRM 1650b.

\begin{tabular}{lcccc}
\cline { 2 - 4 } & $\begin{array}{c}\text { Present work } \\
(\mathbf{n = 3})\end{array}$ & $\begin{array}{c}\text { Nocun and } \\
\text { Schantz (2013) } \\
(\mathbf{n = 3})\end{array}$ & $\begin{array}{c}\text { Layshock et al. } \\
(\mathbf{2 0 1 0}) \\
(\mathbf{n = 3})\end{array}$ & $\begin{array}{c}\text { O'Connell et al. } \\
\mathbf{( 2 0 1 3 )} \\
(\mathbf{n}=\mathbf{5})\end{array}$ \\
\hline 9-FLUO & 20.46 & 25.34 & 24.9 & 19 \\
9,10-ANTH & 31.39 & 53.11 & 47.7 & 64 \\
BFLUO & 8.78 & 15.34 & 15.9 & 18 \\
BEZO & 7.34 & 16.03 & 36.9 & 23 \\
7,12-BaAQ & $\mathrm{BDL}$ & 8.9 & 9 & 5.7 \\
5,12-NAPQ & $\mathrm{BDL}$ & $\mathrm{BDL}$ & $\mathrm{BDL}$ & $\mathrm{BDL}$ \\
B[cd]PYRO & 28.99 & 5.67 & 9.2 & 5 \\
\hline
\end{tabular}




\section{Conclusions}

The present study shows a reliable and relatively simple method to identify and quantify simultaneously 23 polycyclic aromatic hydrocarbons: 16 PAH and 7 oxy-PAH from different samples of soot. The method involves Soxhlet extraction, concentration by rotary evaporation and GC-MS analysis.

The repeatability of the method showed good precision using Printex-U, diesel soot surrogate analysis. The present method accomplishes the objective of identification and quantification of the compounds present in different SRM.

The mass fraction values of oxy-PAH recovered from SRM 1649b showed a good agreement with the values obtained in other studies, while the values corresponding to the SRM 1650b material present some differences.

\section{Acknowledgments and Funding}

The authors express their gratitude to Aragon Government (Ref. T22_17R) co-funded by FEDER 2014-2020 “Construyendo Europa desde Aragón” and to MINECO and FEDER (Project CTQ2015-65226), for financial support. Dr. F. Viteri acknowledges to the "Secretaría Nacional de Educación Superior, Ciencia, Tecnología e Innovación” (SENESCYT) of Ecuador, for the predoctoral grant awarded.

\section{Compliance with Ethical Standards}

Conflict of Interest: The authors declare that they have no conflict of interest. 
Ahmed TM, Bergvall C, Åberg M, Westerholm R. (2015) Determination of oxygenated and native polycyclic aromatic hydrocarbons in urban dust and diesel particulate matter standard reference materials using pressurized liquid extraction and LC-GC/MS. Anal. Bioanal. Chem. 407:427-438. https://doi.org/10.1007/s00216-014-8304-8.

Albinet A, Leoz-Garziandia E, Budzinski H, Viilenave E. (2006) Simultaneous analysis of oxygenated and nitrated polycyclic aromatic hydrocarbons on standard reference material 1649a (urban dust) and on natural ambient air samples by gas chromatography-mass spectrometry with negative ion chemical ionization. J. Chromatogr. A. 1121:106-113. https://doi.org/10.1016/j.chroma.2006.04.043.

Albinet A, Leoz-Garziandia E, Budzinski H, Villenave E, Jaffrezo J-L. (2008) Nitrated and oxygenated derivatives of polycyclic aromatic hydrocarbons in the ambient air of two French alpine valleys Part 1: Concentrations, sources and gas/particle partitioning. Atmos. Environ. 42: 43-54. https://doi.org/10.1016/j.atmosenv.2007.10.009.

Allen JO, Dookeran NM, Taghizadeh K, Lafleur AL, Smith KA, Sarofim AF. (1997) Measurement of oxygenated polycyclic aromatic hydrocarbons associated with a size-segregated urban aerosol. Environ. Sci. Technol. 31:2064-2070. https://doi.org/10.1021/es960894g.

Arnal C, Alzueta MU, Millera Á, Bilbao R. (2012) Influence of water vapor addition on soot oxidation at high temperature. Energy 43:55-63. https://doi.org/10.1016/j.energy.2012.03.036. 
Atribak I, Bueno-López A, García-García A. (2010) Uncatalysed and catalysed soot combustion under $\mathrm{NO}_{\mathrm{x}}+\mathrm{O}_{2}$ : Real diesel versus model soots. Combust Flame 157:2086-2094. https://doi.org/10.1016/j.combustflame.2010.04.01. $\mathrm{PM}_{2.5}$-bound oxygenated PAHs, nitro-PAHs and parent-PAHs from the atmosphere of a Chinese megacity: seasonal variation, sources and cancer risk $\begin{array}{lllll}\text { assessment. } & \text { Sci. } & \text { Total } & \text { Environ. 2014; } & \text { 473-474:77-87. }\end{array}$ https://doi.org/10.1016/j.scitotenv.2013.11.108.

Bosetti C, Boffetta P, La Vecchia C. (2007) Occupational exposures to polycyclic aromatic hydrocarbons, and respiratory and urinary tract cancers: A quantitative review to 2005. Ann. Oncol. 18:431-446. https://doi.org/10.1093/annonc/mdl172. Choi NR, Kim YP, Ji WH, Hwang G-S, Ahn YG. (2016) Identification and quantification of seven volatile n-nitrosamines in cosmetics using gas chromatography/chemical ionization-mass spectrometry coupled with head space-solid phase microextraction. Talanta. 148:69-74. https://doi.org/10.1016/j.talanta.2015.10.045.

Durant JL, Busby Jr WF, Lafleur AL, Penman BW, Crespi CL. (1996) Human cell mutagenicity of oxygenated, nitrated and unsubstituted polycyclic aromatic hydrocarbons associated with urban aerosols. Mutat Res. 371:123-157. https://doi.org/10.1016/S0165-1218(96)90103-2.

Fu PP, Xia Q, Sun X, Yu H. (2012) Phototoxicity and environmental transformation of polycyclic aromatic hydrocarbons (PAHs)-light-induced reactive oxygen species, lipid peroxidation, and DNA damage, J. Environ. Sci. 
Health Pt. C-Environ. Carcinog. Ecotoxicol. Rev. 30:1-41. https://doi.org/10.1080/10590501.2012.653887.

Gómez JÁ, Wenzl T. (2009) Evaluation of gas chromatography columns for the analysis of the $15+1$ EU-priority polycyclic aromatic hydrocarbons (PAHs). Anal Bioanal Chem. 393:1697-1707. https://doi.org/10.1007/s00216-008-2585-8.

Hattemer-Frey HA, Travis CC. (1991) Benzo-a-Pyrene: environmental partitioning and human exposure. Toxicol. Ind. Health 7:141-157. https://doi.org/10.1177/074823379100700303.

Lampi MA, Gurska J, McDonald KIC, Xie F, Huang X-D, Dixon DG, et al. (2005) Photoinduced toxicity of polycyclic aromatic hydrocarbons to Daphnia magna: ultraviolet-mediated effects and the toxicity of polycyclic aromatic hydrocarbon photoproducts, Environ. Toxicol. Chem. 25: 1079-1087. https://doi.org/10.1897/05-276R.1.

Layshock JA, Wilson G, Anderson KA. (2010) Ketone and quinone-substituted polycyclic aromatic hydrocarbons in mussel tissue, sediment, urban dust, and diesel particulate matrices, Environ. Toxicol. Chem. 29:2450-2460. https://doi.org/10.1002/etc.301.

Lundstedt S, White PA, Lemieux CL, Lynes KD, Lambert IB, Öberg L, et al. (2007) Sources, fate, and toxic hazards of oxygenated polycyclic aromatic hydrocarbons (PAHs) at PAH-contaminated sites. Ambio. 36:475-485. https://doi.org/10.1579/0044-7447(2007)36.

Mahuzier P-E, Altria KD, Clark BJ. (2001) Selective and quantitative analysis of 4-hydroxybenzoate preservatives by microemulsion electrokinetic 
chromatography. J. Chromatogr. A. 924:465-470. https://doi.org/10.1016/S00219673(01)00717-8.

Masiol M, Hofer A, Squizzato S, Piazza R, Rampazzo G, Pavoni B. (2012)

Carcinogenic and mutagenic risk associated to airborne particle-phase polycyclic aromatic hydrocarbons: A source apportionment, Atmos. Environ. 60:375-382. https://doi.org/10.1016/j.atmosenv.2012.06.073.

Mathieu O, Frache G, Djebaïli-Chaumeix N, Paillard C-E, Krier G, Muller J-F, et al. (2007) Characterization of adsorbed species on soot formed behind reflected shock waves. Proc. Combust. Inst. 31:511-519. https://doi.org/10.1016/j.proci.2006.07.190.

NIST. National Institute of Standards and Technology NIST. (2009) Certificate of Analysis, Standard Reference Material 1649b, Urban Dust. Gaithersburg.

NIST. National Institute of Standards and Technology. (2013) Certificate of Analysis, Standard Reference Material 1650b, Diesel Particulate Matter. Gaithersburg.

Nocun MS, Schantz MM. (2013) Determination of selected oxygenated polycyclic aromatic hydrocarbons (oxy-PAHs) in diesel and air particulate matter standard reference materials (SRMs). Anal. Bioanal. Chem. 405:5583-5593. https://doi.org/10.1007/s00216-013-6957-3.

O'Connell SG, Haigh T, Wilson G, Anderson KA. (2013) An analytical investigation of 24 oxygenated-PAHs (OPAHs) using liquid and gas chromatography-mass spectrometry, Anal. Bioanal. Chem. 405:8885-8896. https://doi.org/10.1007/s00216-013-7319-x. 

Assessing risks to adults and preschool children posed by $\mathrm{PM}_{2.5}$-bound polycyclic aromatic hydrocarbons (PAHs) during a biomass burning episode in Northern Thailand, Sci. Total Environ. 508:435-444. https://doi.org/10.1016/j.scitotenv.2014.12.019.

Richter H, Howard JB. (2000) Formation of polycyclic aromatic hydrocarbons and their growth to soot-a review of chemical reaction pathways. Prog. Energy Combust. Sci. 26:565-608. https://doi.org/10.1016/S0360-1285(00)00009-5.

Sadezky A, Muckenhuber H, Grothe H, Niessner R, Pöschl U. (2005) Raman microspectroscopy of soot and related carbonaceous materials: Spectral analysis and structural information.

Carbon $43: 1731-1742$. https://doi.org/10.1016/j.carbon.2005.02.018.

Sánchez NE, Salafranca J, Callejas A, Millera Á, Bilbao R, Alzueta MU. (2013) Quantification of polycyclic aromatic hydrocarbons (PAHs) found in gas and particle phases from pyrolytic processes using gas chromatography-mass spectrometry (GC-MS). 107:246-253. https://doi.org/10.1016/j.fuel.2013.01.065. Schantz MM. (2006) Pressurized liquid extraction in environmental analysis, Anal. Bioanal. Chem. 386:1043-1047. https://doi.org/10.1007/s00216-006-06482. Shen G, Tao S, Wang W, Yang Y, Ding J, Xue M, et al. (2011) Emission of oxygenated polycyclic aromatic hydrocarbons from indoor solid fuel combustion. Environ. Sci. Technol. 45:3459-3465. https://doi.org/10.1021/es104364t

Walgraeve C, Chantara S, Sopajaree K, De Wispelaere P, Demeestere K, Van Langenhove H. (2015) Quantification of PAHs and oxy-PAHs on airborne 
particulate matter in Chiang Mai, Thailand, using gas chromatography high resolution mass spectrometry. Atmos. Environ. 107:262-272. https://doi.org/10.1016/j.atmosenv.2015.02.051. 


\title{
Joint quantification of PAH and oxy-PAH from standard reference materials (urban dust and diesel particulate matter) and diesel soot surrogate by GC-MS
}

\author{
F. Viteri ${ }^{\text {b,a }}$, D. Pezo ${ }^{\mathrm{a}}$, Á. Millera ${ }^{\mathrm{a}}$, R. Bilbao ${ }^{\mathrm{a}}$, M.U. Alzueta ${ }^{\mathrm{a}^{*}}$

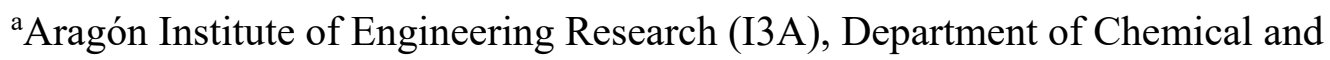 \\ Environmental Engineering, University of Zaragoza, Zaragoza 50018, Spain \\ ${ }^{\mathrm{b}}$ Facultad de Ciencias de la Ingeniería e Industrias. Universidad UTE. Quito - Ecuador. \\ *Corresponding author: Phone: +34976761876, e-mail address: uxue@unizar.es
}

\section{SUPPLEMENTARY MATERIAL}

\section{Table of contents}

1) Qualitative analysis

Table S1. Results of qualitative analysis of Printex-U, SRM 1649b and 1650b samples by GC-MS SCAN mode, $2 \mu \mathrm{L}$ of injection volume.

RT: Retention Time

Match: Can be defined as a factor that indicates correlation between structure of the detected compound and the compound present in the database. 
Table S1. Results of qualitative analysis of Printex-U, SRM 1649b and 1650b samples by GC-MS SCAN mode, $2 \mu \mathrm{L}$ of injection volume.

\begin{tabular}{|c|c|c|c|c|c|c|c|}
\hline $\begin{array}{l}\text { Peak } \\
\text { number }\end{array}$ & RT (min) & Compounds & CAS number & Match & & Samples & \\
\hline 1 & 10.501 & cis-4,4-Dimethyl-2-pentene & 0000762-63-0 & 53 & Printex-U & & \\
\hline 2 & 10.664 & 3-Methyl-1-pentene & $000760-20-3$ & 59 & Printex-U & SRM 1649b & \\
\hline 3 & 11.758 & 1,1-Dichloro-2,2-dichloroethane & 000079-34-5 & 95 & Printex-U & SRM 1649b & SRM 1650b \\
\hline 4 & 13.993 & Benzaldehyde & $000100-52-7$ & 94 & Printex-U & & \\
\hline 5 & 14.547 & Dodecane & 000112-40-3 & 93 & Printex-U & & \\
\hline 6 & 16.050 & Benzyl alcohol & 000100-51-6 & 96 & Printex-U & & SRM $1650 \mathrm{~b}$ \\
\hline 7 & 19.854 & Tetradecane & 000629-59-4 & 96 & Printex-U & & \\
\hline 8 & 20.682 & Naphthalene & 000091-20-3 & 93 & Printex-U & SRM 1649b & SRM $1650 \mathrm{~b}$ \\
\hline 9 & 21.413 & Benzo[c]thiophene & $000270-82-6$ & 95 & Printex-U & & \\
\hline 10 & 21.432 & 2-Hydroxy-5-chlorobenzaldehyde & 000635-93-8 & 98 & & SRM 1649b & \\
\hline 11 & 23.257 & Quinoline & $000091-22-5$ & 97 & Printex-U & & \\
\hline 12 & 23.541 & 1-Methylnaphthalene & 000090-12-0 & 96 & Printex-U & & \\
\hline 13 & 24.318 & 2-Methylnaphthalene & $000091-57-6$ & 96 & Printex-U & & \\
\hline 14 & 24.770 & Heptadecane & 000629-78-7 & 97 & Printex-U & & \\
\hline 15 & 26.096 & Biphenyl & 000092-52-4 & 95 & Printex-U & & \\
\hline 16 & 26.171 & 1,6-Dimethylnaphthalene & 000575-43-9 & 94 & Printex-U & & \\
\hline 17 & 26.236 & 1,7-Dimethylnaphthalene & 000575-37-1 & 95 & Printex-U & & \\
\hline 18 & 26.376 & Phthalic anhydride & 000085-44-9 & 91 & Printex-U & & \\
\hline 19 & 26.799 & 2,6-Dimethylnaphthalene & 000581-42-0 & 98 & Printex-U & & \\
\hline 20 & 26.967 & 2,7-Dimethylnaphthalene & 000582-16-1 & 97 & Printex-U & & \\
\hline 21 & 27.502 & 2,3-Dimethylnaphthalene & 000581-40-8 & 97 & Printex-U & & \\
\hline 22 & $27.828-27.833$ & 2,2,4-Trimethyl-1,3-pentanediol diisobutyrate & 006846-50-0 & 90 & & SRM 1649b & SRM $1650 \mathrm{~b}$ \\
\hline 23 & 28.689 & 3-Methylbiphenyl & 000643-93-6 & 94 & Printex-U & & \\
\hline 24 & 29.043 & 4-Methylbiphenyl & 000644-08-6 & 94 & Printex-U & & \\
\hline 25 & 29.243 & Acenaphthylene & 000208-96-8 & 90 & Printex-U & SRM 1649b & SRM $1650 b$ \\
\hline
\end{tabular}




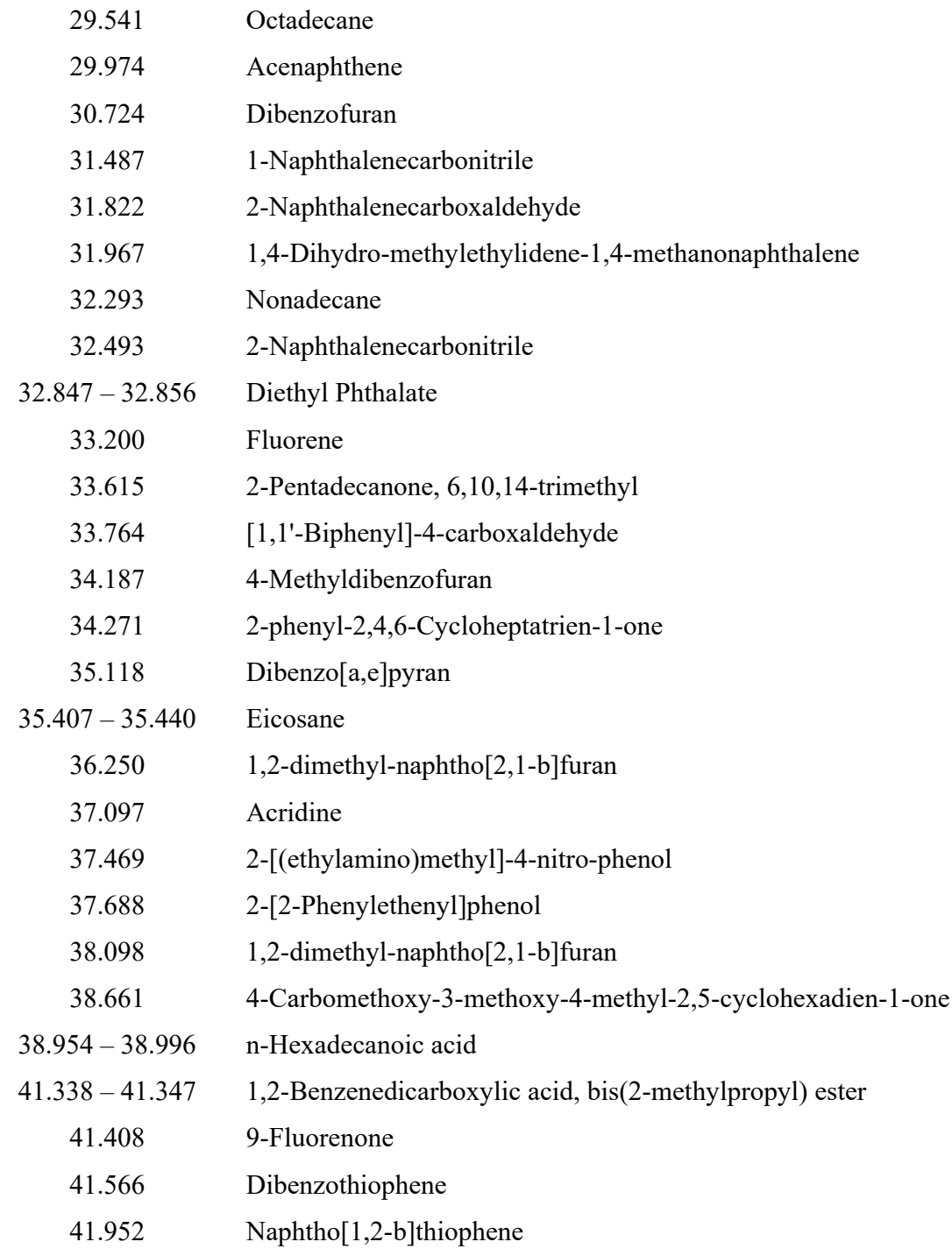

\begin{tabular}{|c|c|c|c|c|}
\hline $000593-45-3$ & 97 & Printex-U & SRM 1649b & SRM $1650 \mathrm{~b}$ \\
\hline $000083-32-9$ & 83 & Printex-U & SRM 1649b & SRM $1650 \mathrm{~b}$ \\
\hline 000132-64-9 & 87 & Printex-U & & \\
\hline $000086-53-3$ & 97 & Printex-U & & \\
\hline 000066-99-9 & 98 & Printex-U & & \\
\hline $007350-72-3$ & 76 & Printex-U & & \\
\hline 000629-92-5 & 96 & Printex-U & SRM 1649b & SRM $1650 \mathrm{~b}$ \\
\hline 000613-46-7 & 97 & Printex-U & & \\
\hline 000084-66-2 & 98 & Printex-U & SRM 1649b & SRM $1650 \mathrm{~b}$ \\
\hline 000086-73-7 & 97 & Printex-U & SRM 1649b & SRM $1650 \mathrm{~b}$ \\
\hline 000502-69-2 & 91 & & SRM 1649b & \\
\hline $003218-36-8$ & 91 & Printex-U & & \\
\hline $007320-53-8$ & 89 & Printex-U & & \\
\hline 014562-09-5 & 86 & Printex-U & & \\
\hline 000092-83-1 & 84 & Printex-U & & \\
\hline $000112-95-8$ & 95 & Printex-U & SRM 1649b & SRM $1650 \mathrm{~b}$ \\
\hline $129812-23-3$ & 74 & Printex-U & & \\
\hline 000260-94-6 & 65 & Printex-U & & \\
\hline $1000400-09-7$ & 59 & Printex-U & & \\
\hline $042224-48-6$ & 72 & Printex-U & & \\
\hline $129812-23-3$ & 60 & Printex-U & & \\
\hline $120696-19-7$ & 90 & Printex-U & & \\
\hline $000057-10-3$ & 98 & Printex-U & SRM 1649b & SRM $1650 \mathrm{~b}$ \\
\hline 000084-69-5 & 86 & & SRM 1649b & SRM $1650 \mathrm{~b}$ \\
\hline 000486-25-9 & 95 & Printex-U & SRM 1649b & SRM $1650 \mathrm{~b}$ \\
\hline $000132-65-0$ & 95 & Printex-U & & \\
\hline $000234-41-3$ & 97 & Printex-U & & \\
\hline
\end{tabular}




$\begin{array}{lcl}53 & 42.781-42.790 & \text { Docosane } \\ 54 & 43.084 & \text { Phenanthrene } \\ 55 & 43.223 & \text { Anthracene } \\ 56 & 43.633 & \text { Naphtho[2,1-b]thiophene } \\ 57 & 44.247 & \text { Benzo[h]quinoline } \\ 58 & 44.811 & \text { Acridine } \\ 59 & 45.062 & \text { Dibenzothiophene } \\ 60 & 45.332 & \text { 3-Methyldibenzothiophene } \\ 61 & 45.630 & \text { 9-Ethenyl anthracene } \\ 62 & 46.231-46.240 & \text { Dibutyl phthalate } \\ 63 & 46.314 & \text { Tetraethyl pyrazine } \\ 64 & 46.519 & \text { Benzo[f]isoquinoline } \\ 65 & 46.771 & \text { Anthrone } \\ 66 & 46.938 & \text { 2,6,10-trimethyl tetradecane } \\ 67 & 46.952 & \text { Octacosane } \\ 68 & 47.166 & \text { 1-Methylphenanthrene } \\ 69 & 47.245-47.250 & \text { Octadecanoic acid } \\ 70 & 47.450-47.501 & \text { Naphthalic anhydride } \\ 71 & 47.674-47.702 & \text { 3-Methylphenanthrene } \\ 72 & 47.916 & \text { 2-Methylanthracene } \\ 73 & 48.349 & \text { 1-Phenanthrenol } \\ 74 & 48.609 & \text { 6-Cyclohexylnonadecane } \\ 75 & 49.145 & \text { 1a,9b-dihydro-1H-Cyclopropa[1]phenanthrene } \\ 76 & 49.457 & \text { Naphtho[2,3-b]norbornadiene } \\ 77 & 51.291-51.314 & \text { Tetracosane } \\ 78 & 51.337 & \text { 2-Phenylnaphthalene } \\ 79 & 51.524 & \text { 1,2-Acenaphthylenedione } \\ 63 & & \\ 67 & & \end{array}$

\begin{tabular}{|c|c|c|c|c|}
\hline 000629-97-0 & 96 & & SRM 1649b & SRM $1650 \mathrm{~b}$ \\
\hline 000085-01-8 & 78 & Printex-U & SRM 1649b & SRM 1650b \\
\hline $000120-12-7$ & 95 & Printex-U & SRM 1649b & SRM 1650b \\
\hline $000233-02-3$ & 96 & Printex-U & & \\
\hline $000230-27-3$ & 95 & Printex-U & & \\
\hline 000260-94-6 & 95 & Printex-U & & \\
\hline $000132-65-0$ & 93 & Printex-U & & \\
\hline $016587-52-3$ & 97 & Printex-U & & \\
\hline 002444-68-0 & 96 & Printex-U & & \\
\hline 000084-74-2 & 96 & Printex-U & SRM 1649b & SRM 1650b \\
\hline 038325-19-8 & 64 & Printex-U & & \\
\hline 000229-67-4 & 91 & Printex-U & & \\
\hline 000090-44-8 & 93 & Printex-U & & \\
\hline 014905-56-7 & 91 & & SRM 1649b & \\
\hline 000630-02-4 & 91 & Printex-U & & SRM 1650b \\
\hline 000832-69-9 & 96 & Printex-U & & \\
\hline $000057-11-4$ & 99 & & SRM 1649b & SRM $1650 \mathrm{~b}$ \\
\hline 000081-84-5 & 96 & Printex-U & & SRM 1650b \\
\hline $000832-71-3$ & 94 & Printex-U & & SRM 1650b \\
\hline 000613-12-7 & 90 & Printex-U & & \\
\hline 002433-56-9 & 90 & Printex-U & & \\
\hline $1000357-25-3$ & 91 & & & SRM 1650b \\
\hline 000949-41-7 & 96 & Printex-U & & \\
\hline $107426-38-0$ & 90 & Printex-U & & \\
\hline 000646-31-1 & 98 & & SRM 1649b & SRM 1650b \\
\hline 000612-94-2 & 97 & Printex-U & & \\
\hline $000082-86-0$ & 98 & Printex-U & & \\
\hline
\end{tabular}




\begin{tabular}{|c|c|c|c|c|c|c|c|}
\hline 80 & 52.180 & 1-Docosene & 001599-67-3 & 95 & & SRM 1649b & \\
\hline 81 & 52.189 & Cyclotetracosane & 000297-03-0 & 96 & & & SRM $1650 \mathrm{~b}$ \\
\hline 82 & 52.329 & 2,7-dimethylphenanthrene & $001576-69-8$ & 95 & Printex-U & & \\
\hline 83 & $52.511-52.557$ & 1H-Phenalen-1-one & 000548-39-0 & 94 & Printex-U & & SRM $1650 \mathrm{~b}$ \\
\hline 84 & 53.069 & Anthralin & $001143-38-0$ & 59 & Printex-U & & \\
\hline 85 & 53.097 & n-Heptadecylcyclohexane & 019781-73-8 & 93 & & & SRM $1650 \mathrm{~b}$ \\
\hline 86 & 53.479 & 4-Hydroxy-9-fluorenone & 001986-00-1 & 93 & Printex-U & & \\
\hline 87 & 53.484 & 3,6-Dimethylphenanthrene & $001576-67-6$ & 62 & & & SRM $1650 b$ \\
\hline 88 & 54.037 & 1,7-Dimethylphenanthrene & $000483-87-4$ & 95 & Printex-U & & \\
\hline 89 & $54.270-54.321$ & 9,10 -Anthraquinone & $000084-65-1$ & 98 & Printex-U & SRM 1649b & SRM $1650 b$ \\
\hline 90 & $55.420-55.425$ & Pentacosane & 000629-99-2 & 91 & & SRM 1649b & SRM $1650 b$ \\
\hline 91 & 55.797 & 5,6-Dihydro-4H-benz[de]anthracene & 004389-09-7 & 58 & Printex-U & & \\
\hline 92 & 56.212 & 2,4-Diamino-6-[3,4-dichlorophenyl]-5-methylthieno[2,3-d]pyrimidine & $042160-12-3$ & 60 & & SRM 1649b & \\
\hline 93 & $57.185-57.408$ & Fluoranthene & 000206-44-0 & 96 & Printex-U & SRM 1649b & SRM $1650 b$ \\
\hline 94 & 57.780 & Cyclopenta(def)phenanthrenone & $005737-13-3$ & 98 & Printex-U & & \\
\hline 95 & 57.990 & $1,2,3,6,7,8$-Hexahydropyrene & 001732-13-4 & 70 & Printex-U & & \\
\hline 96 & 58.069 & 4-Phenylpyridine & 000939-23-1 & 35 & & SRM 1649b & \\
\hline 97 & 58.763 & 1,1'-(1,3-butadiyne-1,4-diyl)bisbenzene & 000886-66-8 & 68 & Printex-U & & \\
\hline 98 & 58.842 & Benzo[b]naphtho[2,3-d]furan & $000243-42-5$ & 87 & Printex-U & & \\
\hline 99 & 59.191 & 9-Anthracenecarbonitrile & $001210-12-4$ & 94 & Printex-U & & \\
\hline 100 & 59.219 & Hexacosane & $000630-01-3$ & 94 & & SRM 1649b & \\
\hline 101 & 59.847 & Phenaleno[1,9-bc]thiophene & 079965-99-4 & 90 & Printex-U & & \\
\hline 102 & $60.015-60.313$ & Naphthalic anhydride & $000081-84-5$ & 98 & Printex-U & & SRM $1650 \mathrm{~b}$ \\
\hline 103 & 60.313 & Valerenic acid & 003569-10-6 & 90 & & SRM 1649b & \\
\hline 104 & $60.527-60.732$ & Pyrene & 000129-00-0 & 95 & Printex-U & SRM 1649b & SRM $1650 b$ \\
\hline 106 & 61.011 & 2,10-Dimethyl-2,3,4,5,6,7-hexahydro-1H-2-benzazonine & 077581-13-6 & 86 & Printex-U & & \\
\hline 107 & 61.519 & 11H-Benzo[a]fluorene & 000238-84-6 & 93 & Printex-U & & \\
\hline
\end{tabular}




$\begin{array}{lcl}108 & 61.691 & \text { Pyrene, 1-methyl- } \\ 109 & 61.868-61.877 & \text { cis-9,10-Octadecenoamide } \\ 110 & 62.217 & \text { Benzo[b]naphtho[2,3-d]furan } \\ 111 & 62.734 & \text { Heptacosane } \\ 112 & 63.241 & \text { 2-Methylpyrene } \\ 113 & 63.367 & \text { 2-Methylfluoranthene } \\ 114 & 63.530-63.586 & \text { Methyl dehydroabietate } \\ 115 & 63.855 & \text { Mitotane } \\ 116 & 64.773 & \text { 4-Methylpyrene } \\ 117 & 65.992 & \text { Octacosane } \\ 118 & 66.104 & \text { 11H-Benzo[b]fluorene } \\ 119 & 67.133-67.147 & \text { Bis(2-ethylhexyl) phthalate } \\ 120 & 69.065 & \text { Nonacosane } \\ 121 & 69.121 & \text { 4,4'-Biphenyldicarboxaldehyde } \\ 122 & 69.414 & \text { 11H-Isoindolo[2,1-a]benzimidazol-11-one } \\ 123 & 70.317 & \text { 1,2'-Binaphthalene } \\ 124 & 70.401 & \text { Benzofluorenone } \\ 125 & 71.085 & \text { Benzo[b]naphtho[2,3-d]thiophene } \\ 126 & 71.188 & \text { 5,6-Dihydro-6-oxodibenzo(b,f)-1,4-thiazepine } \\ 127 & 71.732 & \text { Cyclopenta[cd]pyrene } \\ 128 & 72.719 & \text { 3-Chloro-5H-dibenz[b,f]azepine } \\ 129 & 72.845 & \text { 7H-Benz[de]anthracen-7-one } \\ 130 & 73.627 & \text { Benz[a]anthracene } \\ 131 & 74.404 & \text { 3,4-Dihydrocyclopenta(cd)pyrene } \\ 132 & 74.511 & \text { Chrysene } \\ 133 & 74.619 & \text { 9,10-o-Benzenoanthracene } \\ 134 & 74.702 & \text { Hentriacontane } \\ & & \end{array}$

\begin{tabular}{|c|c|c|c|c|}
\hline $002381-21-7$ & 92 & Printex-U & & \\
\hline 000301-02-0 & 99 & Printex-U & SRM 1649b & SRM $1650 \mathrm{~b}$ \\
\hline $000243-42-5$ & 91 & Printex-U & & \\
\hline 000593-49-7 & 85 & & SRM 1649b & \\
\hline $003442-78-2$ & 89 & Printex-U & & \\
\hline $033543-31-6$ & 83 & Printex-U & & \\
\hline $001235-74-1$ & 89 & Printex-U & & SRM $1650 \mathrm{~b}$ \\
\hline $000053-19-0$ & 93 & Printex-U & & \\
\hline $003353-12-6$ & 96 & Printex-U & & \\
\hline $000630-02-4$ & 99 & & SRM 1649b & \\
\hline $000243-17-4$ & 70 & Printex-U & & \\
\hline $000117-81-7$ & 99 & Printex-U & SRM 1649b & SRM $1650 \mathrm{~b}$ \\
\hline $000630-03-5$ & 94 & & SRM 1649b & \\
\hline $000066-98-8$ & 41 & Printex-U & & \\
\hline $002717-05-7$ & 59 & Printex-U & & \\
\hline $004325-74-0$ & 96 & Printex-U & & \\
\hline $000479-79-8$ & 98 & Printex-U & SRM 1649b & SRM 1650b \\
\hline $000243-46-9$ & 98 & Printex-U & & \\
\hline 003159-07-7 & 64 & Printex-U & & \\
\hline $027208-37-3$ & 95 & Printex-U & & \\
\hline 039607-90-4 & 59 & Printex-U & & \\
\hline $000082-05-3$ & 94 & Printex-U & & \\
\hline $000056-55-3$ & 96 & Printex-U & SRM 1649b & SRM $1650 \mathrm{~b}$ \\
\hline $025732-74-5$ & 95 & Printex-U & & \\
\hline 000218-01-9 & 89 & Printex-U & SRM 1649b & SRM $1650 \mathrm{~b}$ \\
\hline $000477-75-8$ & 89 & Printex-U & & \\
\hline 000630-04-6 & 96 & & SRM 1649b & \\
\hline
\end{tabular}




\begin{tabular}{|c|c|c|c|c|c|c|c|}
\hline 135 & 74.861 & N-phenylthiazolo[4,5-c]pyridin-2-amine & $1000400-95-0$ & 50 & Printex-U & & \\
\hline 136 & 75.089 & 9-Phenylanthracene & $000602-55-1$ & 95 & Printex-U & & \\
\hline 137 & 76.132 & 3,3,5,5-Tetramethyl-2,3,5,6-tetrahydro-S-indacene-1,7-dione & $055591-17-8$ & 58 & Printex-U & & \\
\hline 138 & 77.370 & Benzanthrone & $000082-05-3$ & 96 & Printex-U & SRM $1649 b$ & SRM $1650 \mathrm{~b}$ \\
\hline 139 & 78.701 & 2-phenylphenanthrene & $004325-77-3$ & 86 & Printex-U & & \\
\hline 140 & 79.656 & 2,2'-Binaphthalene & 000612-78-2 & 95 & Printex-U & & \\
\hline 141 & 79.888 & Benz(a)anthracene-7,12-dione & 002498-66-0 & 83 & Printex-U & SRM 1649b & SRM 1650b \\
\hline 142 & 83.748 & Naphthacene-5,12-dione & 001090-13-7 & 83 & Printex-U & SRM 1649b & \\
\hline 143 & 86.001 & 1,2-Diphenyl-3-chlorocarbonyl-cyclopropene & 006415-58-3 & 53 & & SRM 1649b & \\
\hline 144 & 86.033 & Benzo[b]fluoranthene & $000205-99-2$ & 99 & Printex-U & SRM 1649b & SRM $1650 \mathrm{~b}$ \\
\hline 145 & 86.322 & Benzo[k]fluoranthene & 000207-08-9 & 97 & Printex-U & SRM 1649b & SRM $1650 \mathrm{~b}$ \\
\hline 146 & 86.760 & Perylene & 000198-55-0 & 95 & Printex-U & & \\
\hline 147 & 87.044 & Aceanthrenequinone & $006373-11-1$ & 42 & Printex-U & & \\
\hline 148 & 87.667 & 4,5-Dihydrobenzo[a]pyrene & $57652-66-1$ & 78 & Printex-U & & \\
\hline 149 & 90.689 & Benzo[a]pyrene & $000050-32-8$ & 96 & Printex-U & SRM 1649b & SRM $1650 \mathrm{~b}$ \\
\hline 150 & 91.354 & Benzo[e]pyrene & 000192-97-2 & 98 & Printex-U & & \\
\hline 151 & 92.993 & Benzo[j]fluoranthene & $000205-82-3$ & 96 & Printex-U & & \\
\hline 152 & 93.105 & Benzo[cd]pyrenone & 003074-00-8 & 96 & Printex-U & SRM 1649b & SRM $1650 \mathrm{~b}$ \\
\hline 153 & 98.700 & Biacenaphthenylidene & $002435-82-7$ & 55 & Printex-U & & \\
\hline 154 & 104.510 & Indeno[1,2,3-cd]pyrene & 000193-39-5 & 95 & Printex-U & SRM 1649b & SRM 1650b \\
\hline 155 & 105.474 & Dibenz[a,h]anthracene & $000053-70-3$ & 38 & Printex-U & SRM 1649b & SRM $1650 \mathrm{~b}$ \\
\hline 156 & 105.972 & Dibenzo[def,mno]chrysene & 000191-26-4 & 94 & Printex-U & & \\
\hline 157 & 110.842 & Benzo[ghi]perylene & 000191-24-2 & 96 & Printex-U & SRM $1649 \mathrm{~b}$ & SRM $1650 \mathrm{~b}$ \\
\hline
\end{tabular}

